\title{
Rhizobium daejeonense sp. nov. isolated from a cyanide treatment bioreactor
}

\author{
Zhe-Xue Quan, ${ }^{1} \dagger$ Hee-Sung Bae, ${ }^{1,2}$ Jong-Hwan Baek, ${ }^{1}$ Wen-Feng Chen, ${ }^{3}$ \\ Wan-Taek $\mathrm{Im}^{1}$ and Sung-Taik Lee ${ }^{1}$ \\ 'Department of Biological Sciences, Korea Advanced Institute of Science and Technology, \\ 373-1 Guseong-dong, Yuseong-gu, Daejeon 305-701, Korea \\ ${ }^{2}$ Department of Biological Sciences, 331 Life Sciences Building, Louisiana State University, \\ Baton Rouge, LA 70803, USA \\ ${ }^{3}$ College of Biological Sciences, China Agricultural University, Beijing 100094, China
}

Correspondence

Sung-Taik Lee

e_stlee@kaist.ac.kr
A polyphasic study was carried out to determine the taxonomic position of two aerobic, cyanide-degrading bacterial strains, designated $\mathrm{L} 61^{\top}$ and $\mathrm{L} 22$, which had been isolated from a bioreactor for the treatment of nickel-complexed cyanide. The two isolates exhibited almost identical taxonomic characteristics. Phylogenetic analysis inferred from comparative 16S rRNA gene sequences indicated that the isolates fall in a sublineage of the genus Rhizobium comprising the type strains of Rhizobium giardinii, Rhizobium radiobacter, Rhizobium rubi, Rhizobium larrymoorei, Rhizobium vitis, Rhizobium undicola, Rhizobium loessense, Rhizobium galegae and Rhizobium huautlense. Cells of the two isolates are Gram-negative, aerobic, motile and non-spore-forming rods $(0.6-0.7 \times 1.1-1.3 \mu \mathrm{m})$, with peritrichous flagella. The DNA $\mathrm{G}+\mathrm{C}$ content is $60 \cdot 1-60 \cdot 9 \mathrm{~mol} \%$. Cellular fatty acids are $\mathrm{C}_{16: 0}(2 \cdot 2-3 \cdot 3 \%), \mathrm{C}_{18: 0}(2 \cdot 1-3 \cdot 2 \%)$, $\mathrm{C}_{19: 0}$ cyclo $\omega 8 \mathrm{c}(9 \cdot 9-16 \cdot 8 \%), \mathrm{C}_{20: 3} \omega 6,9,12 c(2 \cdot 7-3 \cdot 3 \%)$, summed feature $3(7 \cdot 2-7 \cdot 7 \%)$ and summed feature $7(67 \cdot 8-73 \cdot 7 \%)$. The strains formed nodules on a legume plant, Medicago sativa. A nifH gene encoding denitrogenase reductase, the key component of the nitrogenase enzyme complex, was detected in $\mathrm{L} 61^{\top}$ by PCR amplification by using a nifH-specific primer system. Strains $L 61^{\top}$ and $L 22$ were distinguished from the type strains of recognized Rhizobium species in the same sublineage based on low DNA-DNA hybridization values (2-4\%) and/or a $16 \mathrm{~S}$ rRNA gene sequence similarity value of less than $96 \%$. Moreover, some phenotypic properties with respect to substrate utilization as a carbon or nitrogen source, antibiotic resistance and growth conditions could be used to discriminate $\mathrm{L} 61^{\top}$ and $\mathrm{L} 22$ from Rhizobium species in the same sublineage. Based on the results obtained in this study, $\mathrm{L} 61^{\top}$ and $\mathrm{L} 22$ are considered to be representatives of a novel species of Rhizobium, for which the name Rhizobium daejeonense sp. nov. is proposed. The type strain is ${\mathrm{L} 61^{\top}}^{\top}\left(=\mathrm{KCTC} 12121^{\top}=\operatorname{IAM} 15042^{\top}=\mathrm{CCBAU}_{10050^{\top}}\right)$.
Since the first description of the genus Rhizobium for rootand/or stem-nodule bacteria by Frank (1889), a number of

Published online ahead of print on 12 August 2005 as DOI 10.1099/ ijs.0.63667-0.

tPresent address: Department of Microbiology and Microbial Engineering, School of Life Sciences, Fudan University, Shanghai 200433, China.

The GenBank/EMBL/DDBJ accession numbers for the 16S rRNA gene sequences of strains $L 61^{\top}$ and $L 22$ are AY341343 and D0089696, respectively. The GenBank/EMBL/DDBJ accession number for the partial nifH gene sequence of strain $L 61^{\top}$ is $A Y 428644$.

A transmission electron micrograph of cells of strain $L 61^{\top}$, a minimumevolution phylogenetic tree and a table detailing the fatty acid compositions of $L 61^{\top}, \mathrm{L} 22$ and related Rhizobium species are available as supplementary material in IJSEM Online. revisions and additions of novel species into this genus have been made. Currently, the genus Rhizobium includes 20 recognized species: Rhizobium galegae, $R$. huautlense, $R$. vitis, R. undicola, R. rubi, R. radiobacter, R. loessense, $R$. larrymoorei, $R$. mongolense, $R$. sullae, $R$. hainanense, $R$. leguminosarum, $R$. etli, $R$. tropici, $R$. rhizogenes, $R$. giardinii, R. gallicum, R. indigoferae, R. lupini and R. phaseoli.

Cyanides have been regarded as toxic pollutants because of their inhibitory effect on cytochrome oxidase in respiratory electron transport chains; therefore, most countries request the complete removal of cyanide from wastewater effluent before discharge. Toxic cyanides have been known to be oxidized by various species of bacteria, fungi, yeast and plants. Isolations were made here of the cyanide-degrading bacterial population found in a bioreactor. Comparative 
$16 \mathrm{~S}$ rRNA gene sequence analysis indicated that the two strains isolated, $\mathrm{L} 61^{\mathrm{T}}$ and $\mathrm{L} 22$, were members of the clade representing the genus Rhizobium. The strains were the subject of further study. Many aerobic bacteria and fungi capable of degrading cyanides have been isolated, including Pseudomonas sp. NCIB 11764 (Harris \& Knowles, 1983), Burkholderia cepacia C-3 (Adjei \& Ohta, 1999) and Alcaligenes xylosoxidans DF-3 (Ingvorsen et al., 1991). However, to our knowledge, no Rhizobium species has been reported in this population. It is also unusual for rhizobia to inhabit an activated sludge. In order to determine the precise taxonomic position of strains $\mathrm{L} 61^{\mathrm{T}}$ and L22, a polyphasic study was carried out. Based on the results obtained, we suggest that $\mathrm{L} 61^{\mathrm{T}}$ is the type strain of a novel species of Rhizobium.

Strains $\mathrm{L} 61^{\mathrm{T}}$ and $\mathrm{L} 22$ were isolated from a nickel-complexed cyanide treatment bioreactor that had been inoculated with an activated sludge from a municipal sewage treatment plant (Daejeon, Korea). The bioreactor had been run by supplying a basal medium (BM) comprising $1.25 \mathrm{~g} \mathrm{~K}_{2} \mathrm{HPO}_{4}, 0.38 \mathrm{~g}$ $\mathrm{KH}_{2} \mathrm{PO}_{4}, 0.2 \mathrm{~g} \mathrm{NaSO}_{4}, 0.06 \mathrm{~g} \mathrm{CaCl}_{2} .2 \mathrm{H}_{2} \mathrm{O}, 0.06 \mathrm{~g} \mathrm{MgCl}_{2}$, $0.72 \mathrm{~g}$ glucose and $82.5 \mathrm{mg} \mathrm{K}_{2}\left[\mathrm{Ni}(\mathrm{CN})_{4}\right]$ in 11 distilled water. For the isolation of cyanide-degrading bacteria, a sample of the consortium $(0 \cdot 1 \mathrm{~g})$ taken from the reactor on day 30 of the operation was suspended in $1 \mathrm{ml} \mathrm{BM}$. After serially diluting the suspension with $\mathrm{BM}, 0 \cdot 1 \mathrm{ml}$ diluted suspension was spread on BM agar plates [BM components plus $1.5 \%(\mathrm{w} / \mathrm{v})$ agar] and was incubated at $28{ }^{\circ} \mathrm{C}$ in the dark. After 2 weeks of incubation, single colonies that appeared on the plates were transferred on to newly prepared plates, and were incubated again under the same conditions for the purification of colonies. The cyanide degradation activity of the purified isolates was tested in liquid BM containing cyanides. Reference organisms used in this study, R. giardinii $\mathrm{H} 152^{\mathrm{T}}$ (=KACC $10720^{\mathrm{T}}$ ), $R$. huautlense $\mathrm{S}_{2}^{\mathrm{T}}$ ( = KACC $10738^{\mathrm{T}}$ ), R. galegae ATCC $43677^{\mathrm{T}}$ $\left(=\right.$ KACC $10639^{\mathrm{T}}$ ), R. radiobacter DSM $30148^{\mathrm{T}}$ (= KACC $\left.10736^{\mathrm{T}}\right)$, R. rubi IFO $13261^{\mathrm{T}}\left(=\mathrm{KACC} 10739^{\mathrm{T}}\right)$ and $R$. vitis NCPPB $3554^{\mathrm{T}}$ (=KACC $10777^{\mathrm{T}}$ ), were obtained from Korean Agricultural Culture Collection (KACC).

Morphological features of the cells grown on YMA for 3 days were determined with a phase-contrast microscope

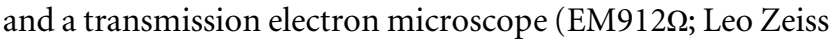
Inc.) after negative staining with $1 \%(\mathrm{w} / \mathrm{v})$ phosphotungstic acid. Gram staining and catalase and oxidase tests were performed following the protocols outlined by Smibert \& Krieg (1981). Some physiological properties and substrate utilizations were determined by means of the API $20 \mathrm{NE}$ and API 32 GN systems, in accordance with the manufacturer's instructions (bioMérieux). An antibiotic resistance test and determination of the $\mathrm{NaCl}$ concentration and $\mathrm{pH}$ range for growth were performed in YMA, as described by Gao et al. (1994). Utilization of nitrogen sources, including cyanides $\mathrm{KCN}$ and $\mathrm{K}_{2}\left[\mathrm{Ni}(\mathrm{CN})_{4}\right]$ was tested in modified White's medium (White, 1972). Cellular fatty acids were extracted from cells grown on TY medium (Beringer, 1974) for 3 days, as described by Jarvis et al. (1996). The fatty acids were analysed by means of a gas chromatograph (Hewlett Packard 6890) equipped with the Microbial Identification software package (Sasser, 1990).

Genomic DNA was extracted by using a Qiagen DNeasy tissue kit in accordance with the manufacturer's protocols. RNA was removed from the DNA solution by treating with a mixture of RNases A and T1 (each at $20 \mathrm{Uml}^{-1}$ ) at $30{ }^{\circ} \mathrm{C}$ for $1 \mathrm{~h}$. PCR amplification of the 16S rRNA gene was performed by using a bacterial universal primer set, 9F $\left(5^{\prime}\right.$-GAGTTTGATCCTGGCTCAG-3') and 1512R [5'ACGG(A/T/C)TACCTTGTTACGACTT-3']. The thermal profile used was an initial denaturation step at $94^{\circ} \mathrm{C}$ for 5 min, 30 cycles consisting of 1 min denaturation at $94{ }^{\circ} \mathrm{C}$, $30 \mathrm{~s}$ of primer annealing at $55^{\circ} \mathrm{C}$ and $2 \mathrm{~min}$ of extension at $72{ }^{\circ} \mathrm{C}$, plus a $7 \mathrm{~min}$ final extension at $72^{\circ} \mathrm{C}$. The PCR product was purified with a QIAquick PCR purification kit and was then sequenced by using an ABI Prism BigDye Terminator cycle sequencing ready reaction kit and a 3700 DNA Analyser (both Applied Biosystems). For full sequencing, primers 519F (5'-CAGCAGCCGCGGTAATAC-3'), 907F [5'-AAACTCAAA(G/T)GAATTGACGG-3'], 536R (5'-GTATTACCGCGGCTGCTG -3') and 1100R (5'-GGGTTGCGCTCGTTG-3') were used. The partial sequences were aligned and combined by using the BIOEDIT program (Hall, 1999). Sequences of related Rhizobium species were obtained from GenBank. These collected sequences were aligned with the CLUSTAL X program (Thompson et al., 1997). Evolutionary distances were calculated using the Kimura two-parameter model (Kimura, 1983) and the phylogenetic tree was constructed by using three tree-building methods, neighbourjoining (Saitou \& Nei, 1987), minimum-evolution (Rzhetsky \& Nei, 1992) and maximum-parsimony (Swofford, 1993), in the MEGA 2 program (Kumar et al., 2001). A bootstrap method was used to obtain confidence levels with 1000 replications (Felsenstein, 1985). A nifH gene was amplified by means of PCR using a PolF-PolR primer system designed by Poly et al. (2001).

DNA-DNA hybridization values were estimated fluorometrically using photobiotin-labelled DNA probes and microdilution wells according to the method of Ezaki et al. (1989). From five repetitions, three values, excluding the highest and the lowest, were used for the estimation. The hybridization temperature was $55^{\circ} \mathrm{C}$. The DNA G $+\mathrm{C}$ content was determined by using the procedure described by Mesbah et al. (1989).

A nodulation test was carried out in a test tube $(50 \times$ $200 \mathrm{~mm}$ ) containing a quarter-strength nitrogen-free plant nutrient solution (Vincent, 1970), which had been autoclaved for $3 \mathrm{~h}$. Surface-sterilized germinated seedlings of Glycine max, Phaseolus vulgaris, Pisum sativum and Medicago sativa were planted aseptically in each tube. The tubes were inoculated with the culture broth (YM broth, $1.5 \mathrm{ml}$ ) of strain $\mathrm{L} 61^{\mathrm{T}}$ with approximately 100 cells $\mathrm{ml}^{-1}$. The plants were grown at $25^{\circ} \mathrm{C}$ for 6 weeks in a greenhouse under natural radiation that was supplemented with fluorescent lamps to lengthen the photoperiod to $12 \mathrm{~h}$. 


\begin{tabular}{|c|c|c|c|c|c|c|c|c|c|c|c|}
\hline \multicolumn{12}{|c|}{ 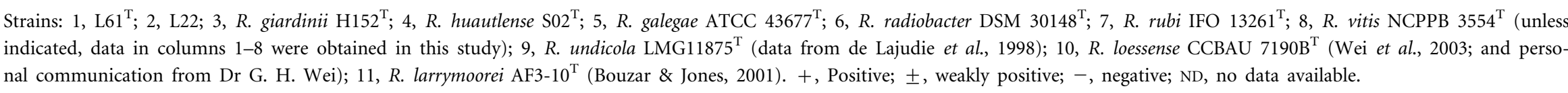 } \\
\hline Characteristic & 1 & 2 & 3 & 4 & 5 & 6 & 7 & 8 & 9 & 10 & 11 \\
\hline Origin & $\begin{array}{l}\text { Bioreactor } \\
\text { treating } \\
\text { cyanide } \\
\text { (Korea) }\end{array}$ & $\begin{array}{l}\text { Bioreactor } \\
\text { treating } \\
\text { cyanide } \\
\text { (Korea) }\end{array}$ & $\begin{array}{l}\text { Phaseolus } \\
\text { vulgaris } \\
(\text { France })^{a_{\star}}\end{array}$ & $\begin{array}{c}\text { Sesbania } \\
\text { herbacea } \\
(\text { Mexico })^{b}\end{array}$ & $\begin{array}{c}\text { Galega } \\
\text { orientalis } \\
(\text { Finland })^{c}\end{array}$ & ND & ND & ND & $\begin{array}{l}\text { Neptunia } \\
\text { natans } \\
\text { (Senegal) }\end{array}$ & $\begin{array}{l}\text { Astragalus } \\
\text { campanatus } \\
\text { (China) }\end{array}$ & $\begin{array}{c}\text { Ficus } \\
\text { benjamina } \\
\text { (Florida) }\end{array}$ \\
\hline Cell morphology & $\begin{array}{c}\text { Rods } \\
(0 \cdot 7 \times 1 \cdot 3 \mu \mathrm{m})\end{array}$ & Rods & $\begin{array}{c}\text { Rods } \\
(0 \cdot 5-0 \cdot 7 \times \\
1 \cdot 6-2 \cdot 2 \mu \mathrm{m})^{a}\end{array}$ & $\mathrm{ND}$ & $\begin{array}{c}\text { Rods } \\
(0 \cdot 9-1 \cdot 0 \times \\
1 \cdot 5-1 \cdot 8)^{c}\end{array}$ & ND & ND & ND & $\begin{array}{c}\text { Rods } \\
(0 \cdot 5-0 \cdot 7 \times \\
2-4 \mu \mathrm{m})\end{array}$ & $\begin{array}{c}\text { Rods } \\
(0 \cdot 5-0 \cdot 7 \times \\
1 \cdot 8-2 \cdot 1 \mu \mathrm{m})\end{array}$ & Rods \\
\hline Flagella & $\begin{array}{c}\text { Several, } \\
\text { peritrichous }\end{array}$ & $\begin{array}{c}\text { Several, } \\
\text { peritrichous }\end{array}$ & $\mathrm{ND}$ & ND & $\begin{array}{l}\text { 1-2, Polar or } \\
\text { subpolar }^{c}\end{array}$ & $\begin{array}{c}\text { Several, } \\
\text { peritrichous }^{d}\end{array}$ & $\begin{array}{c}\text { Several, } \\
\text { peritrichous }^{d}\end{array}$ & $\begin{array}{c}\text { Several, } \\
\text { peritrichous }^{d}\end{array}$ & + & $\mathrm{ND}$ & $\begin{array}{c}\text { Several } \\
\text { peritrichous }\end{array}$ \\
\hline $\begin{array}{l}\text { DNA G+C content } \\
(\mathrm{mol} \%)\end{array}$ & $60 \cdot 1$ & $60 \cdot 9$ & $60 \cdot 2$ & $57 \cdot 0^{b}$ & $63 \cdot 0^{c}$ & $57 \cdot 1$ & $58 \cdot 1$ & $56 \cdot 9$ & $60 \cdot 1$ & $59 \cdot 5$ & $\mathrm{ND}$ \\
\hline Nodulation & + & + & $+^{a}$ & $+^{b}$ & $+^{c}$ & $-{ }^{d}$ & $-{ }^{d}$ & $-{ }^{d}$ & + & + & - \\
\hline $\begin{array}{l}\mathrm{pH} \text { range for growth } \\
\text { Growth at/in: }\end{array}$ & $5 \cdot 0-10 \cdot 0$ & $5 \cdot 0-10 \cdot 0$ & $4 \cdot 0-8 \cdot 5^{a}$ & $5 \cdot 0-9 \cdot 0^{b}$ & $5 \cdot 0-9 \cdot 5^{c}$ & ND & $\mathrm{ND}$ & $\mathrm{ND}$ & $\mathrm{ND}$ & $7 \cdot 0-10 \cdot 0$ & $\mathrm{ND}$ \\
\hline $40^{\circ} \mathrm{C}$ & + & + & $-{ }^{a}$ & $++^{b}$ & $-^{c}$ & ND & $-{ }^{d}$ & ND & ND & - & - \\
\hline $1 \% \mathrm{NaCl}$ & + & + & $\mathrm{d}^{a_{\dagger}}$ & $++^{b}$ & $\mathrm{ND} \ddagger$ & $+{ }^{d}$ & ND & $-{ }^{d}$ & ND & + & + \\
\hline $2 \% \mathrm{NaCl}$ & + & + & $-{ }^{a}$ & $-{ }^{b}$ & $--^{c}$ & $+{ }^{d}$ & $-{ }^{d}$ & $+^{d}$ & ND & + & + \\
\hline \multicolumn{12}{|l|}{$\begin{array}{l}\text { Utilization as carbon } \\
\text { source: }\end{array}$} \\
\hline D-Melibiose & - & - & + & + & + & + & + & + & - & + & + \\
\hline Propionate & + & \pm & \pm & - & - & + & - & - & - & - & ND \\
\hline Caprate & + & + & - & - & - & - & - & - & - & $\mathrm{ND}$ & ND \\
\hline Valerate & + & + & - & - & - & - & - & - & - & - & $\mathrm{ND}$ \\
\hline Histidine & + & + & + & + & - & + & + & + & + & ND & + \\
\hline 2-Ketogluconate & - & - & + & + & + & + & - & - & - & $\mathrm{ND}$ & ND \\
\hline $\mathrm{N}$-Acetylglucosamine & - & - & + & + & \pm & + & + & + & - & $\mathrm{ND}$ & + \\
\hline Malonate & - & - & - & + & - & - & + & - & - & - & - \\
\hline Acetate & + & + & \pm & + & + & + & + & \pm & + & - & - \\
\hline 3-Hydroxybenzoate & + & + & - & + & + & - & - & - & - & ND & ND \\
\hline Maltose & + & + & + & \pm & \pm & + & + & + & + & - & + \\
\hline Gluconate & - & - & + & \pm & + & + & + & \pm & - & - & ND \\
\hline Citrate & - & - & - & - & - & - & - & + & - & - & - \\
\hline
\end{tabular}




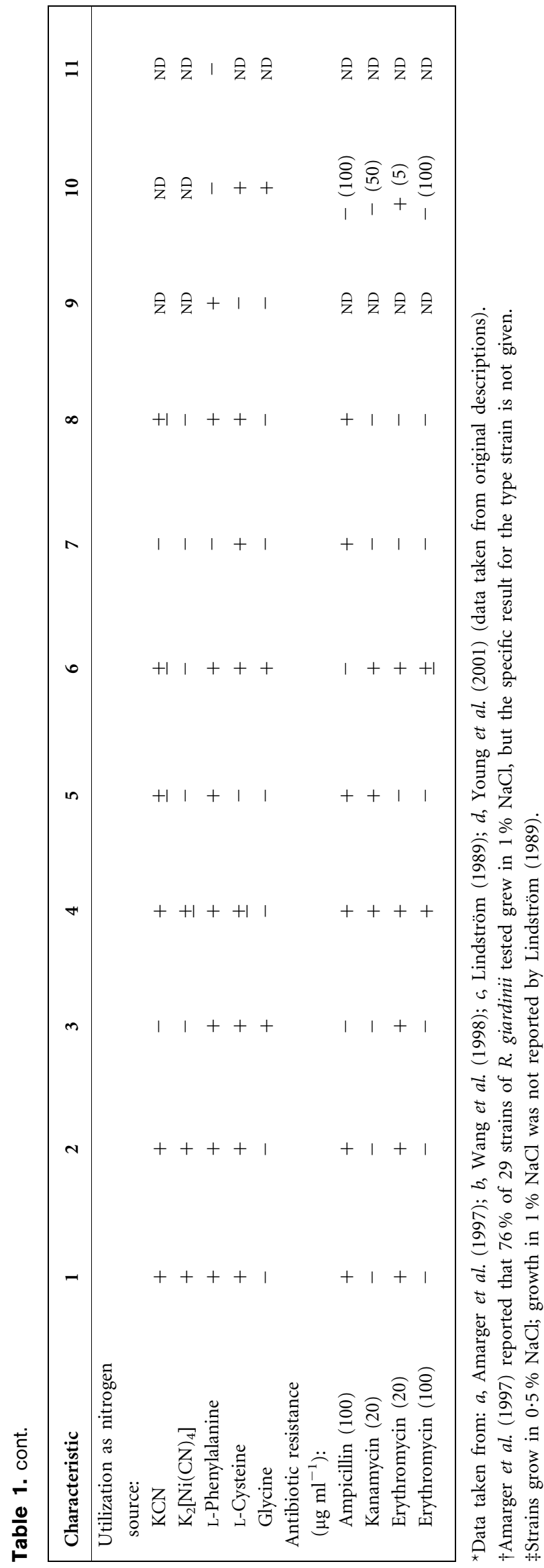

Cells of strains L61 and L22 were aerobic, Gram-negative, motile and non-spore-forming rods. The isolates utilized $2 \mathrm{mM} \mathrm{KCN}$ or $\mathrm{K}_{2}\left[\mathrm{Ni}(\mathrm{CN})_{4}\right]$ as a nitrogen source. Peritrichous flagella were observed under transmission electron microscopy (Supplementary Fig. S1 in IJSEM Online). Available carbon and nitrogen source utilizations and antibiotic resistance are summarized in Table 1. Fatty acid analysis showed that $\mathrm{L} 61^{\mathrm{T}}$ and $\mathrm{L} 22$ contained low levels of $\mathrm{C}_{16: 0}(2 \cdot 2-3 \cdot 3 \%)$ compared with related Rhizobium species $(6 \cdot 6-13 \cdot 4 \%)$ (Supplementary Table S1 in IJSEM Online). Other morphological, phenotypic and chemotaxonomic characteristics of strains $\mathrm{L} 61^{\mathrm{T}}$ and L22 obtained in this study are given in the species description below.

The nearly complete $16 \mathrm{~S}$ rRNA genes of strains $\mathrm{L} 61^{\mathrm{T}}$ (1421 nt) and L22 (1396 nt) were sequenced for phylogenetic analysis. The two strains showed identical 16S rRNA gene sequences. Fig. 1 shows the phylogenetic tree constructed by the neighbour-joining method using these sequences and those of closely related organisms obtained from GenBank. Strains L61 ${ }^{\mathrm{T}}$ and L22 fall in a sub-branch of the genus Rhizobium that comprises the type strains of R. giardinii (16S rRNA gene sequence similarity of $96.9 \%$ ), $R$. radiobacter $(96 \cdot 1 \%)$, R. rubi $(96 \cdot 0 \%)$, $R$. larrymoorei (95.7\%), R. vitis (95.4\%), R. undicola (94.4\%), R. loessense (94.4\%), R. galegae $(94 \cdot 1 \%)$ and R. huautlense (94.9\%). Members of this group also clustered on the same phylogenetic branch when the minimum-evolution (Supplementary Fig. S2 in IJSEM Online) and maximum-parsimony (not shown) tree-building methods were used, indicating that the phylogenetic positions of the two isolates were not affected by the choice of algorithm.

A sequence $\left(360 \mathrm{nt}\right.$ ) from strain $\mathrm{L} 61^{\mathrm{T}}$ was obtained by amplification with nifH primers. This gene sequence showed similarities of $87 \cdot 6,87 \cdot 1$ and $85 \cdot 7 \%$, respectively, when it was aligned with nifH gene sequences from Azospirillum lipoferum 4VI (GenBank accession no. AY786992), Rhizobium sp. TJ167 (AJ505316) and Sinorhizobium americanum CFNEI 54 (AF506515), indicating the presence of nifH in strain $\mathrm{L} 61^{\mathrm{T}}$.

DNA-DNA reassociation is considered to be a standard method for determining species differences (Wayne et al., 1987; Stackebrandt et al., 2002). A species is considered to be represented by a population whose strains share levels of DNA-DNA hybridization of more than 70\%. DNA-DNA hybridization values between strains $\mathrm{L} 1^{\mathrm{T}}$ and $\mathrm{L} 22$ were $86 \%$, suggesting that they represent the same species. Reference species ( $R$. giardinii, $R$. radiobacter, R. rubi, $R$. vitis, $R$. galegae and $R$. huautlense) all had DNA-DNA reassociation values of $2-4 \%$ with strains $L 61^{\mathrm{T}}$ and $\mathrm{L} 22$, indicating a genetic distance that supports these strains as representing a novel species. $R$. undicola, $R$. loessense and $R$. larrymoorei, which clustered with two strains $\mathrm{L}^{\mathrm{T}}{ }^{\mathrm{T}}$ and L22 on one branch of the phylogenetic tree, and other Rhizobium species exhibited 16S rRNA gene sequence similarity values of $<96 \%$; therefore, they could be clearly discriminated from the two new isolates as different species. 


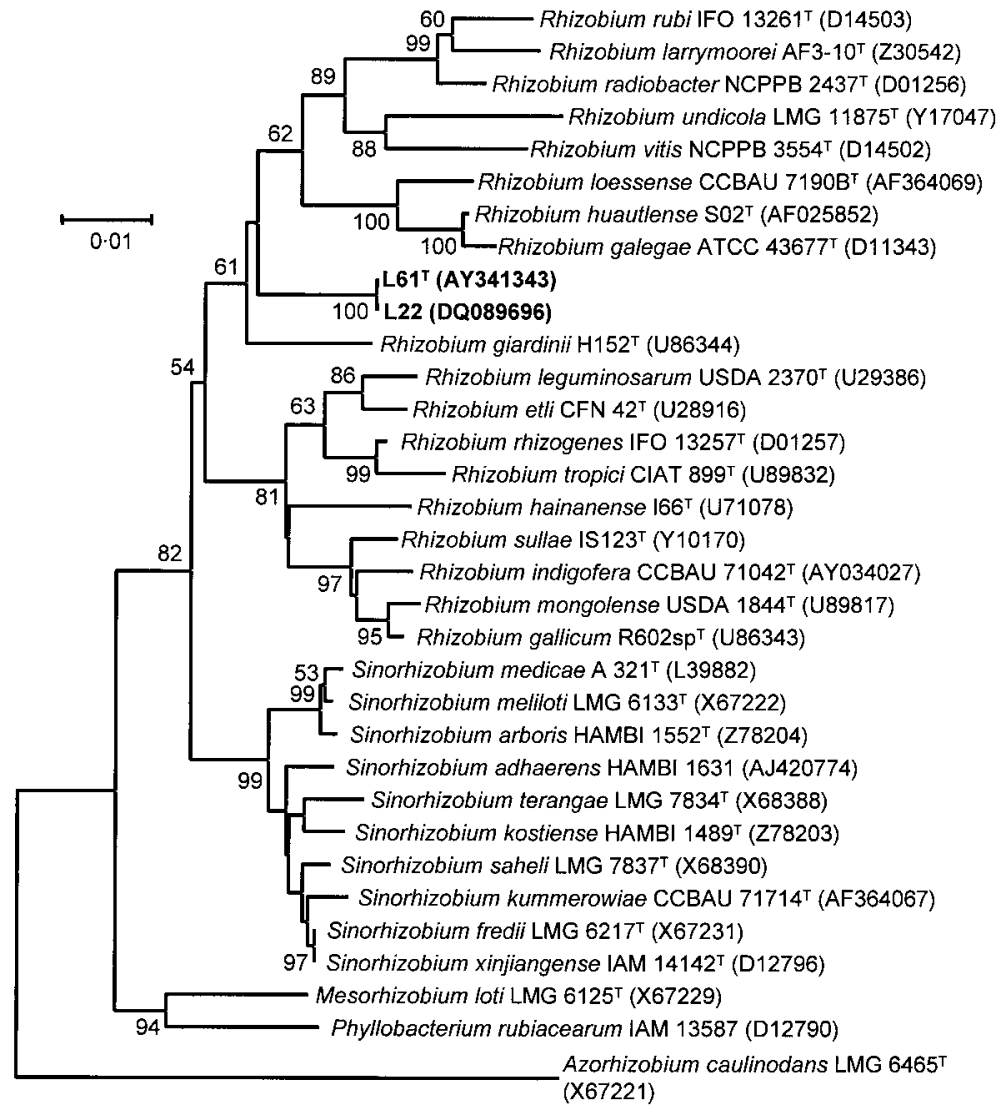

Fig. 1. Neighbour-joining tree showing the phylogenetic relationship of strains $\mathrm{L} 61^{\top}$ and L22, Rhizobium species and other related species of the 'Alphaproteobacteria'. Bootstrap values (expressed as percentages of 1000 replications) above $50 \%$ are shown at branch points. Bar, 0.01 substitutions per nucleotide position.
The DNA G + C content of strains $\mathrm{L} 1^{\mathrm{T}}$ and $\mathrm{L} 22$ was $60 \cdot 1$ and $60.9 \mathrm{~mol} \%$, respectively, values that match closely those of related Rhizobium species (56.9-60.2 mol\%) (Table 1).

Nodulation and nitrogen-fixing ability are typical characteristics of the genus Rhizobium, and may be essential for their symbiotic relationship with legumes. To determine whether strains $\mathrm{L} 61^{\mathrm{T}}$ and $\mathrm{L} 22$ have these functional characteristics, a nodulation test was carried out using four different legumes: G. max, Phaseolus vulgaris, Pisum sativum and $M$. sativa. The two strains successfully formed nodules on $M$. sativa; Medicago includes many species known to be host plants of rhizobia, such as Sinorhizobium meliloti (de Lajudie et al., 1994), Sinorhizobium medicae (Rome et al., 1996) and Rhizobium mongolense (van Berkum et al., 1998).

The phylogenetic data, chemotaxonomic features (DNA $\mathrm{G}+\mathrm{C}$ content, fatty acid composition) and the functional traits of rhizobia (nodulation and nifH) strongly support the classification of strains $\mathrm{L} 61^{\mathrm{T}}$ and $\mathrm{L} 22$ within the genus Rhizobium. The DNA-DNA hybridization values and/or the low 16S rRNA gene sequence similarity values suggest that the two strains represent a novel species in this genus. The two strains could also be distinguished from recognized Rhizobium species based on several important phenotypic characteristics: substrate (carbon or nitrogen sources) utilization, antibiotic resistance, growth conditions $(\mathrm{pH}$, temperature, $\mathrm{NaCl}$ concentrations), as summarized in Table 1, and fatty acid profile (Supplementary Table S1). Based on the results obtained, strains $\mathrm{L} 61^{\mathrm{T}}$ and $\mathrm{L} 22$ can be assigned to be same species, while they are sufficiently distinct from strains of recognized Rhizobium species as to be recognized as representing a novel species. The name Rhizobium daejeonense sp. nov. is proposed.

\section{Description of Rhizobium daejeonense sp. nov.}

Rhizobium daejeonense (dae.jeon.en'se. N.L. neut. adj. daejeonense pertaining to Daejeon, a city in Korea, where the type strain was isolated).

Cells are Gram-negative, aerobic, motile, non-sporeforming rods $(0 \cdot 6-0.7 \times 1 \cdot 1-1.3 \mu \mathrm{m})$ with peritrichous flagella. Colonies appearing on YMA within 3 days of incubation at $28^{\circ} \mathrm{C}$ are circular, cream coloured, semitranslucent and $1 \cdot 5-3 \cdot 0 \mathrm{~mm}$ in diameter. Catalase, oxidase, urease, $\beta$-galactosidase and $\beta$-glucosidase are positive. Gelatin liquefaction, indole production and arginine dihydrolase are negative. No nitrate reduction to nitrite. Cells grow at $41{ }^{\circ} \mathrm{C}$, in $0-2 \% \mathrm{NaCl}$ and over a $\mathrm{pH}$ range of 5-10; however, no growth is observed at 4 or $45^{\circ} \mathrm{C}$, in $2 \cdot 5 \% \mathrm{NaCl}$ or at a $\mathrm{pH}>10$ or $<4 \cdot 5$. Nodules are formed in $M$. sativa by the type strain. A nifH gene encoding a component of the nitrogenase complex is detected. DNA $\mathrm{G}+\mathrm{C}$ content is $60 \cdot 1-60 \cdot 9 \mathrm{~mol} \%$, as determined by 
HPLC. Cellular fatty acids are $\mathrm{C}_{16: 0}(2 \cdot 2-3 \cdot 3 \%), \mathrm{C}_{18: 0}$ $(2 \cdot 1-3 \cdot 2 \%), \mathrm{C}_{19: 0}$ cyclo $\omega 8 c(9 \cdot 9-16 \cdot 8 \%), \mathrm{C}_{20: 3} \omega 6,9,12 c$ $(2 \cdot 7-3 \cdot 3 \%)$, summed feature $3(7 \cdot 2-7 \cdot 7 \%)$ and summed feature $7(67 \cdot 8-73 \cdot 7 \%)$. Carbon sources used include propionate, caprate, valerate, histidine, acetate, L-alanine, 3-hydroxybenzoate, maltose, D-glucose, fucose, D-sorbitol, L-proline, rhamnose, D-ribose, inositol, DL-lactate, arabinose, mannose, mannitol, maltose and malate, but not citrate, itaconate, suberate, glycogen, phenylacetate, adipate, D-melibiose, 2-ketogluconate, $\mathrm{N}$-acetylglucosamine, malonate, 5-ketogluconate or gluconate. L-Glutamic acid, L-methionine, L-phenylalanine, L-cysteine and free and nickel-complexed cyanides are used as nitrogen sources, but DL-tryptophan and glycine are not. Cells are resistant to ampicillin (20 and $100 \mu \mathrm{g} \mathrm{ml}^{-1}$ ) and erythromycin $\left(20 \mu \mathrm{g} \mathrm{ml}^{-1}\right)$, but susceptible to tetracycline $\left(50 \mu \mathrm{g} \mathrm{ml}^{-1}\right)$, erythromycin $\left(100 \mu \mathrm{g} \mathrm{ml}^{-1}\right)$, chloramphenicol $\left(100 \mu \mathrm{g} \mathrm{ml}^{-1}\right)$ and kanamycin $\left(100 \mu \mathrm{g} \mathrm{ml}^{-1}\right)$.

The type strain is $\mathrm{L}^{\mathrm{T}}{ }^{\mathrm{T}}\left(=\mathrm{KCTC} 12121^{\mathrm{T}}=\mathrm{IAM} 15042^{\mathrm{T}}=\right.$ CCBAU $\left.10050^{\mathrm{T}}\right)$ and a reference strain is $\mathrm{L} 22$ ( $=$ KCTC $12120=\mathrm{IAM} 15041)$. The strains were isolated from a cyanide-degrading bioreactor originally inoculated by an activated sludge from a municipal sewage treatment plant (Daejeon, Korea).

\section{Acknowledgements}

We thank Dr Wen-Xin Chen for helpful discussions during the course of this study and thank Dr Ge-Hong Wei for personal communication. This work was supported by the 21C Frontier Microbial Genomics and Application Center Program, Ministry of Science \& Technology (Grant MG05-0101-4-0), Republic of Korea.

\section{References}

Adjei, M. D. \& Ohta, Y. (1999). Isolation and characterization of a cyanide-utilizing Burkholderia cepacia strain. World J Microbiol Biotechnol 15, 699-704.

Amarger, N., Macheret, V. \& Laguerre, G. (1997). Rhizobium gallicum sp. nov. and Rhizobium giardinii sp. nov., from Phaseolus vulgaris nodules. Int J Syst Bacteriol 47, 996-1006.

Beringer, J. E. (1974). R-Factor transfer in Rhizobium leguminosarum. J Gen Microbiol 84, 188-198.

Bouzar, H. \& Jones, J. B. (2001). Agrobacterium larrymoorei sp. nov., a pathogen isolated from aerial tumours of Fucus benjamina. Int J Syst Evol Microbiol 51, 1023-1026.

de Lajudie, P., Willems, A., Pot, B. \& 7 other authors (1994). Polyphasic taxonomy of rhizobia: emendation of the genus Sinorhizobium and description of Sinorhizobium meliloti comb. nov., Sinorhizobium saheli sp. nov., and Sinorhizobium teranga sp. nov. Int J Syst Bacteriol 44, 715-733.

de Lajudie, P., Laurent-Fulele, E., Willems, A., Torck, U., Coopman, R., Collins, M. D., Kersters, K., Dreyfus, B. \& Gillis, M. (1998). Allorhizobium undicola gen. nov., sp. nov., nitrogen-fixing bacteria that efficiently nodulate Neptunia natans in Senegal. Int $J$ Syst Bacteriol 48, 1277-1290.

Ezaki, T., Hashimoto, Y. \& Yabuuchi, E. (1989). Fluorometric deoxyribonucleic acid-deoxyribonucleic acid hybridization in microdilution wells as an alternative to membrane filter hybridization in which radioisotopes are used to determine genetic relatedness among bacterial strains. Int J Syst Bacteriol 39, 224-229.

Felsenstein, J. (1985). Confidence limits on phylogenies: an approach using the bootstrap. Evolution 39, 783-791.

Frank, B. (1889). Ueber die Pilzsymbiose der Leguminosen. Ber Dtsch Bot Ges 7, 332-346 (in German).

Gao, J. L., Sun, J. G., Li, Y., Wang, E. T. \& Chen, W. X. (1994). Numerical taxonomy and DNA relatedness of tropical rhizobia isolated from Hainan province, China. Int $J$ Syst Bacteriol 44, 151-158.

Hall, T. A. (1999). BIOEDIT: a user-friendly biological sequence alignment editor and analysis program for Windows 95/98/NT. Nucleic Acids Symp Ser 41, 95-98.

Harris, R. \& Knowles, C. J. (1983). Isolation and growth of a Pseudomonas species that utilizes cyanide as a source of nitrogen. J Gen Microbiol 129, 1005-1011.

Ingvorsen, K., Hǿjer-Pedersen, B. \& Godtfredsen, S. E. (1991). Novel cyanide-hydrolyzing enzyme from Alcaligenes xylosoxidans subsp. denitrificans. Appl Environ Microbiol 57, 1783-1789.

Jarvis, B. D. W., Sivakumaran, S., Tighe, S. W. \& Gillis, M. (1996). Identification of Agrobacterium and Rhizobium species based on cellular fatty acid composition. Plant Soil 184, 143-158.

Kimura, M. (1983). The Neutral Theory of Molecular Evolution. Cambridge: Cambridge University Press.

Kumar, S., Tamura, K., Jacobsen, I. B. \& Nei, M. (2001). MEGA2: molecular evolutionary genetics analysis software. Bioinformatics 17, 1244-1245.

Lindström, K. (1989). Rhizobium galegae, a new species of legume root nodule bacteria. Int J Syst Bacteriol 39, 365-367.

Mesbah, M., Premachandran, U. \& Whitman, W. B. (1989). Precise measurement of the $\mathrm{G}+\mathrm{C}$ content of deoxyribonucleic acid by highperformance liquid chromatography. Int J Syst Bacteriol 39, 159-167.

Poly, E., Monrozier, L. J. \& Bally, R. (2001). Improvement in the RFLP procedure for studying the diversity of nifH genes in communities of nitrogen fixers in soil. Res Microbiol 152, 95-103.

Rome, S., Fernandez, M. P., Brunel, B., Norman, P. \& Cleyet-Marel, J.-C. (1996). Sinorhizobium medicae sp. nov., isolated from annual Medicago spp. Int J Syst Bacteriol 46, 972-980.

Rzhetsky, A. \& Nei, M. (1992). A simple method for estimating and testing minimum-evolution trees. Mol Biol Evol 9, 945-967.

Saitou, N. \& Nei, M. (1987). The neighbor-joining method: a new method for reconstructing phylogenetic trees. Mol Biol Evol 4, 406-425.

Sasser, M. (1990). Identification of bacteria by gas chromatography of cellular fatty acids. MIDI Technical Note 101. Newark, DE: MIDI Inc.

Smibert, R. M. \& Krieg, N. R. (1981). General characterization. In Manual of Methods for General Bacteriology, pp. 409-443. Edited by P. Gerhardt, R. G. E. Murray, R. N. Costilow, E. W. Nester, W. A. Wood, N. R. Krieg \& G. B. Phillips, Washington, DC: American Society for Microbiology.

Stackebrandt, E., Frederiksen, W., Garrity, G. M. \& 10 other authors (2002). Report of the ad hoc committee for the re-evaluation of the species definition in bacteriology. Int J Syst Evol Microbiol 52, 1043-1047.

Swofford, D. L. (1993). PAUP: Phylogenetic Analysis Using Parsimony, version 3.1.1. Champaign, IL: Illinois Natural History Survey.

Thompson, J. D., Gibson, T. J., Plewniak, F., Jeanmougin, F. \& Higgins, D. G. (1997). The CLUSTAL_X windows interface: flexible strategies for multiple sequence alignment aided by quality analysis tools. Nucleic Acids Res 25, 4876-4882. 
van Berkum, P., Beyene, D., Bao, G., Campbell, T. A. \& Eardly, B. D. (1998). Rhizobium mongolense sp. nov. is one of three rhizobial genotypes identified which nodulate and form nitrogen-fixing symbioses with Medicago ruthenica [(L.) Ledebour]. Int J Syst Bacteriol 48, 13-22.

Vincent, J. M. (1970). A Manual for the Practical Study of Root Nodule Bacteria. Oxford: Blackwell Scientific.

Wang, E. T., van Berkum, P., Beyene, D., Sui, X. H., Dorado, O., Chen, W. X. \& Martinez-Romero, E. (1998). Rhizobium huautlense sp. nov., a symbiont of Sesbania herbacea that has a close phylogenetic relationship with Rhizobium galegae. Int J Syst Bacteriol 48, 687-699.

Wayne, L. G., Brenner, D. J., Colwell, R. R. \& 9 other authors (1987). Report of the ad hoc committee on reconciliation of approaches to bacterial systematics. Int J Syst Bacteriol 37, 463-464.
Wei, G. H., Tan, Z. Y., Zhu, M. E., Wang, E. T., Han, S. Z. \& Chen, W. X. (2003). Characterization of rhizobia isolated from legume species within the genera Astragalus and Lespedeza grown in the Loess Plateau of China and description of Rhizobium loessense sp. nov. Int $J$ Syst Evol Microbiol 53, 1575-1583.

White, L. O. (1972). The taxonomy of the crown gall organism Agrobacterium tumefaciens and its relationship to rhizobia and other agrobacteria. J Gen Microbiol 72, 565-574.

Young, J. M., Kuykendall, L. D., Martínez-Romero, E., Kerr, A. \& Sawada, H. (2001). A revision of Rhizobium Frank 1889, with an emended description of the genus, and the inclusion of all species of Agrobacterium Conn 1942 and Allorhizobium undicola de Lajudie et al. 1998 as new combinations: Rhizobium radiobacter, $R$. rhizogenes, R. rubi, R. undicola and R. vitis. Int J Syst Evol Microbiol 51, 89-103. 